\title{
Growth after Renal Transplantation in Prepubertal Children: Impact of Various Treatment Modalities
}

A. C. S. HOKKEN-KOELEGA, M. A. E. VAN ZAAL, M. A. J. DE RIDDER, E. D. WOLFF, M. C. J. W. DE JONG, R. A. DONCKERWOLCKE, S. M. P. F. DE MUINCK KEIZER-SCHRAMA, AND S. L. S. DROP

\author{
Department of Pediatrics, Division of Endocrinology and Nephrology, Sophia Children's Hospital/Erasmus \\ University, Rotterdam /A.C.S.H.-K, M.A.E.V.Z., E.D.W., S.M.P.F.M.K.-S., S.L.S.D.J; Radboud Hospital, \\ Nijmegen [M.C.J.W.d.J.]; Wilhelmina Children's Hospital, Utrecht [R.A.D.J; and Department of Epidemiology' \\ and Biostatistics, Erasmus University, Rotterdam [M.A.J.d.R.], The Netherlands
}

\begin{abstract}
A retrospective study evaluated posttransplant growth of 70 prepubertal children during the first 2 y after renal transplantation ( $\mathrm{RTX})$. Immunosuppressive treatment consisted of prednisone administered either daily or on alternate days in combination with either azathioprine or cyclosporin $\mathrm{A}$. The increment in height standard deviation score for chronologic age during the first $2 \mathrm{y}$ after RTx was less than $0.5 \mathrm{SD}$ for $70 \%$ of the study population. The predictive factors for posttransplant growth were determined by evaluating several factors and treatment modalities singly and simultaneously in a multiple regression analysis. Patients with the most severe growth retardation at RTx appeared to have the most pronounced growth spurt after RTx, but even they never had complete catchup growth, and 2 y after RTx they were still shorter than those with less severe growth retardation at RTx. Alternate-day instead of daily prednisone administration had a significantly positive influence, whereas a high cumulative dose of prednisone, azathioprine instead of cyclosporin $A$ therapy, and a persistently reduced GFR (GFR $<50 \mathrm{~mL}$ / $\min / 1.73 \mathrm{~m}^{2}$ ) had a significantly negative influence on catch-up growth during the $\mathbf{2} \mathrm{y}$ after RTx. Other factors, such as gender, chronologic and bone age at RTx, primary renal disease, duration of initial dialysis, repeat $R T x$, and target height SD score for chronologic age, whether evaluated singly or simultaneously with other significant factors, appeared to have no significant influence on post-RTx growth. Thus, $70 \%$ of the prepubertal children do not experience appreciable catch-up growth during the first 2 y after RTx. Optimization of pretransplant height appears very important. Immunosuppressive treatment with cyclosporin therapy in combination with a minimal dose of alternate-day prednisone would then result in optimal posttransplant growth, particularly if the GFR remains above $50 \mathrm{~mL} / \mathrm{min} / 1.73 \mathrm{~m}^{2}$ ). (Pediatr Res 35: 367-371, 1994)
\end{abstract}

\section{Abbreviations}

RTx, renal transplantation

$\mathrm{hSDS}_{\mathrm{CA}}$, height standard deviation score for chronologic age

CsA, cyclosporin A

Aza, azathioprine

Received June 24, 1993; accepted October 14, 1993.

Correspondence and reprint requests: A. C. S. Hokken-Koelega, Department of Pediatrics, Division of Endocrinology, Sophia Children's Hospital, Dr. Molewaterplein 60,3015 GJ Rotterdam. The Netherlands.

Supported by Novo Nordisk, Denmark.
SDS $_{\mathrm{CA}}$, standard deviation score for chronologic age

One of the major problems preventing satisfactory rehabilitation of children after successful RTx is short stature. Many adults who received kidney transplants during childhood have a final height below the 3 rd height percentile (1; Hokken-Koelega et al., unpublished manuscript). Much of the growth deficit occurs because of poor growth before RTx, particularly during infancy and while undergoing dialysis $(3,4)$. Growth rates may improve after RTx, but it seldom leads to sufficient catch-up growth (5). Prednisone therapy might be a major cause of poor growth after RTx. Alternate-day rather than daily administration of prednisone has been reported to have a beneficial effect on growth $(6$; Hokken-Koelega et al., unpublished manuscript), and the use of CsA instead of Aza may lead to improved growth rates $(7,8)$. Posttransplant growth may also be influenced by several other factors, such as renal graft function and chronologic age and bone age at the time of RTx (9). Unfortunately, most studies only focus on the effect of one or other specific factor on growth after RTx, not taking into account the complex and probably interrelated effects of various factors combined.

We therefore evaluated, retrospectively, the posttransplant growth of 70 strictly prepubertal children during the first $2 y$ after RTx, including assessment of the impact of several variables simultaneously. These variables included gender, primary renal disease, chronologic and bone age at RTx, duration of first dialysis period, graft function, and various treatment modalities after RTx.

\section{PATIENTS AND METHODS}

From February 1972 to May 1990, 212 pediatric patients younger than $15 \mathrm{y}$ of age received their first functioning renal allograft (RTx) at one of the three pediatric centers involved in this study. This number represents the majority of all Dutch children who underwent first RTx (95\% cadaveric) during this period, excluding those with renal allografts that ceased to function within $3 \mathrm{~d}$ after RTx. We evaluated the growth data of these patients retrospectively, with the exclusion of 63 patients. Eighteen of these 63 patients had died within 1 y after RTx, six had received androgen therapy before $\mathrm{RTx}$, eight had either cystinosis or oxalosis, the records of 25 patients were incomplete, and six refused to have their data included. For the present study we selected 70 ( 47 boys and 23 girls) of the remaining 149 patients, all of whom had remained prepubertal (Tanner stage 1) (10) for $2 \mathrm{y}$ after their first RTx. 
Data were collected from the start of the first dialysis up to 2 $y$ after the first RTx. The patients had been monitored regularly during this period, and the following items were noted: height; weight; sexual maturation; serum creatinine level; episodes and type of dialysis and number of RTx; type and dose of immunosuppressive drugs including prednisone regimen; occurrence of acute or chronic rejection episodes (diagnosed by renal biopsy, increased serum creatinine level, fever, hypertension, decreased urine output, or renal scintigraphy); and bone age if appropriate. The primary renal disease and the parents' heights were also recorded. Height had been measured with a Harpenden stadiometer, and expressed in centimeters and hSDS ${ }_{\mathrm{CA}}$. Height standards of healthy Dutch children were used as reference data (11). Bone maturation was determined from radiographs of the left hand and wrist using the method of Greulich and Pyle (12). Pubertal maturation was recorded according to Tanner's scale (10). Parent's height served to calculate the target height for each individual patient. Secular trend was taken into account: father's + mother's height $\pm 12 \mathrm{~cm} / 2,+3 \mathrm{~cm}$ (13). Target height in centimeters was converted into target $\mathrm{hSDS}_{\mathrm{CA}}$ with Dutch standards for final height (11). We determined the GFR in these children during the $2 \mathrm{y}$ after RTx with the method described by Morris (14): (height in $\mathrm{cm} \times 40$, divided by serum creatinine level in $\mu \mathrm{mol} / \mathrm{L}$ ) and expressed as $\mathrm{mL} / \mathrm{min} / 1.73 \mathrm{~m}^{2}$.

All children received immunosuppressive medication consisting of prednisone and either Aza or CsA. Prednisone administration started on the day of RTx at a dose of $3 \mathrm{mg} / \mathrm{kg} / \mathrm{d}$, tapering off to $1 \mathrm{mg} / \mathrm{kg} / \mathrm{d}$ during the first $3 \mathrm{mo}$ postoperatively. Subsequently, prednisone therapy was reduced to a maintenance dose of $0.15-0.30 \mathrm{mg} / \mathrm{kg} / \mathrm{d}$. Two prednisone regimens were used: administration was either daily or on alternate days. Acute rejection episodes were treated with either $20 \mathrm{mg} / \mathrm{kg}$ i.v. methylprednisolone on alternate days for a period of $10-14 \mathrm{~d}$ or oral prednisone in an initial dose of $200 \mathrm{mg} / 1.73 \mathrm{~m}^{2}$, which was reduced every $3 \mathrm{~d}$ to taper off to a maintenance dose in the course of $15 \mathrm{~d}$. Until 1984, Aza was given adjuvantly, starting immediately after RTx at a dose of $3 \mathrm{mg} / \mathrm{kg} / \mathrm{d}$ and tapering off to a maintenance dose of $2 \mathrm{mg} / \mathrm{kg} / \mathrm{d}$ or less. From 1984, several children received CsA instead of Aza adjuvant to prednisone. CsA was also started the day of RTx at a dose of $14 \mathrm{mg} / \mathrm{kg} / \mathrm{d}$, tapering off to a maintenance dose of $7-8 \mathrm{mg} / \mathrm{kg} / \mathrm{d}$ or even less depending on plasma levels of CsA (desired plasma level of therapeutic CsA from 3 mo after RTx: $30-70 \mathrm{ng} / \mathrm{mL}$ ).

For each individual patient, we calculated the percentage of time on alternate-day prednisone administration, the cumulative dose of prednisone $(\mathrm{mg} / \mathrm{kg})$, the percentage of time on either Aza or CsA treatment, and the total duration (years) of a reduced GFR ( $<50 \mathrm{~mL} / \mathrm{min} / 1.73 \mathrm{~m}^{2}$ ) during the $2 \mathrm{y}$ after RTx.

Two-sample $t$ test was used to assess differences between two groups. To study the influence of a number of variables on the change in hSDS ${ }_{\mathrm{CA}}$ during 2 y after $\mathrm{RTx}\left(\Delta \mathrm{hSDS}_{\mathrm{CA}}\right)$, we carried out a simple linear regression analysis involving the association between a continuous variable and the $\Delta \mathrm{hSDS}_{\mathrm{CA}}$, whereby each variable was considered singly. To determine the influence on $\triangle \mathrm{hSDS} \mathrm{CA}_{\mathrm{A}}$ of several variables simultaneously, we then carried out multiple regression analyses. This first involved a stepwise, backward elimination procedure on the variables known at the time of the first RTx [i.e. gender $(1=$ male), duration of initial dialysis period (years), primary renal disease $(1=$ urinary tract abnormalities, or renal hypoplasia, or both; $2=$ glomerulopathies; 3 = nephrotic syndrome), chronologic and bone age at first RTx (years), hSDS ${ }_{C A}$, and target hSDS $_{C A}$ ]. Next, the model was extended in a backward selection manner, also stepwise, adding the posttransplant variables [i.e. percentage of time on alternateday prednisone, cumulative dose of prednisone (counted per 100 $\mathrm{mg} / \mathrm{kg}$ ), length of time (years) that GFR remained below $50 \mathrm{~mL} /$ $\mathrm{min} / 1.73 \mathrm{~m}^{2}$, Aza versus CsA for more than $85 \%$ of time (1 versus 0$)$ ]; all concerned the first 2 y after RTx.

\section{RESULTS}

Clinical data of our 70 prepubertal patients ( 47 boys and 23 girls) are summarized in Table 1 . The primary renal disease consisted of glomerulopathies in 35 patients $(50.0 \%)$, urinary tract abnormalities and/or renal hypoplasia in 25 patients $(35.7 \%)$, and nephrotic syndrome in eight patients $(11.4 \%)$. This information was not available for the remaining two boys $(2.9 \%)$. Sixty-five children underwent dialysis before their first RTx; 33 boys and 14 girls were on hemodialysis, whereas 11 boys and seven girls had peritoneal dialysis. Five children, three boys and two girls, did not have dialysis before their first RTx. During the 2 y after RTx, 40 children $(57 \%)$ had stable grafts with a GFR above $50 \mathrm{~mL} / \mathrm{min} / 1.73 \mathrm{~m}^{2}$, whereas 30 children $(43 \%)$ had deterioration of renal function. For 5 of them (7\%), this meant only a temporary decrease of the GFR to less than $50 \mathrm{~mL} / \mathrm{min}$ / $1.73 \mathrm{~m}^{2}$ with normal values at the end of the $2 \mathrm{nd}$ y after RTx; $18(26 \%)$ had progressive graft deterioration to a persistent GFR below $50 \mathrm{~mL} / \mathrm{min} / 1.73 \mathrm{~m}^{2}$, two of whom had a second RTx within $2 \mathrm{y}$; seven (10\%) resumed dialysis after acute progression to graft failure, three of whom also had a second RTx during the first 2 y after RTx.

Growth. Height SDS $_{\mathrm{CA}}$ for each individual patient is presented in Figure 1 at initiation of dialysis, at the first RTx, at $12 \mathrm{mo}$ and at 24 mo after RTx in relationship to the mean target

Table 1. Clinical data of 70 prepubertal children

\begin{tabular}{|c|c|c|}
\hline & $\begin{array}{c}\text { Boys } \\
(n=47)\end{array}$ & $\begin{array}{c}\text { Girls } \\
(n=23)\end{array}$ \\
\hline \multicolumn{3}{|l|}{ Primary renal disease } \\
\hline $\begin{array}{l}\text { Congenital (urinary abnor- } \\
\text { malities) }(n)\end{array}$ & 18 & 7 \\
\hline $\begin{array}{l}\text { Acquired (glomerulopa- } \\
\text { thy) }(n)\end{array}$ & 22 & 13 \\
\hline Nephrotic syndrome $(n)$ & 5 & 3 \\
\hline Unknown $(n)$ & 2 & 0 \\
\hline \multicolumn{3}{|l|}{ First dialysis } \\
\hline $\begin{array}{l}\text { Chronologic age in years } \\
\text { (range) }\end{array}$ & $7.3(1.3$ to 11.3$)$ & $7.4(3.7$ to 11.6$)$ \\
\hline Duration in years (range) & $1.1(0.2$ to 7.4$)$ & $0.8(0.3$ to 3.2$)$ \\
\hline \multicolumn{3}{|l|}{ Type } \\
\hline Hemodialysis $(n)$ & 33 & 14 \\
\hline $\begin{array}{l}\text { Continuous ambulatory } \\
\text { peritoneal dialysis }(n)\end{array}$ & 11 & 7 \\
\hline \multicolumn{3}{|l|}{ First RTx } \\
\hline $\begin{array}{l}\text { Chronologic age in years } \\
\text { (range) }\end{array}$ & $8.0(2.2$ to 12.1$)$ & $8.6(3.0$ to 12.0$)$ \\
\hline Bone age in years (range) & $6.5(2.2$ to 11.1$)$ & 6.9 (2.9 to 11.2$)$ \\
\hline \multicolumn{3}{|l|}{ Prednisone therapy } \\
\hline \multicolumn{3}{|l|}{$\begin{array}{l}\text { Percentage of time on al- } \\
\text { ternate-day predni- } \\
\text { sone }\end{array}$} \\
\hline $0 \%(n)$ & 21 & 16 \\
\hline $10-60 \%(n)$ & 17 & 3 \\
\hline$>60 \%(n)$ & 9 & 4 \\
\hline \multicolumn{3}{|l|}{ Immunosuppressive therapy } \\
\hline \multicolumn{3}{|l|}{ Percentage of time on aza } \\
\hline$>85 \%(n)$ & 34 & 17 \\
\hline $20-60 \%(n)$ & 4 & 2 \\
\hline $0 \%(n)$ & 9 & 4 \\
\hline \multicolumn{3}{|l|}{$\begin{array}{l}\text { Renal graft function } 2 \text { y after } \\
\text { RTx }\end{array}$} \\
\hline $\begin{array}{l}\underset{\mathrm{m}^{2 *}}{\mathrm{GFR}}>50 \mathrm{~mL} / \mathrm{min} / 1.73 \\
\end{array}$ & 32 & 13 \\
\hline $\begin{array}{c}\text { GFR }<50 \mathrm{~mL} / \mathrm{min} / 1.73 \\
\mathrm{~m}^{2} \dagger\end{array}$ & 12 & 6 \\
\hline
\end{tabular}

* Including five patients who had a temporary decline in GFR during these $2 \mathrm{y}$.

† Mean (range) duration: $1.2(0.1-2.0)$ y. 


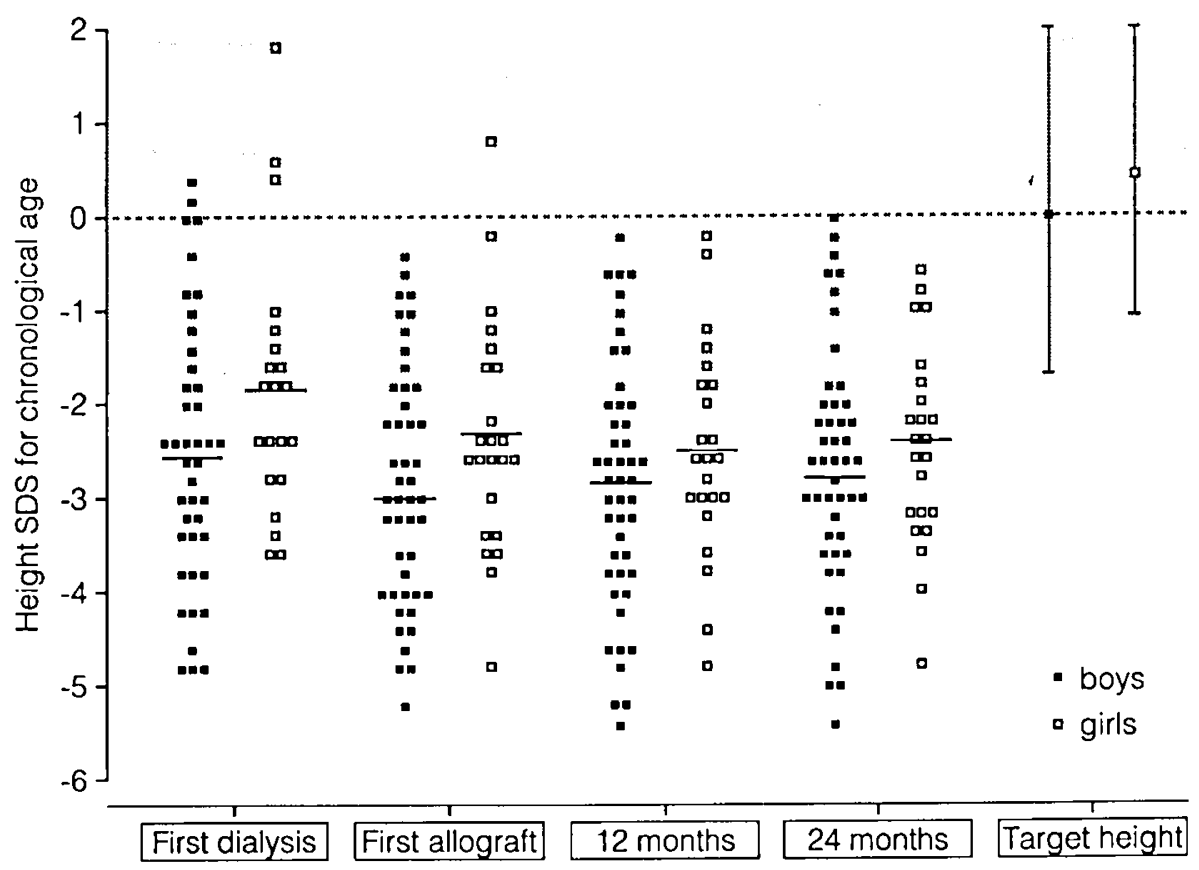

Fig. 1. Individual and mean $\mathrm{hSDS}_{\mathrm{CA}}$ from first dialysis through $2 \mathrm{y}$ after first RTx and mean (range) target hSDS $\mathrm{CA}_{\mathrm{A}}$ for 70 prepubertal patients. Dotted area represents $94 \%$ of the healthy Dutch reference population (the area between the 3 rd and 97 th height percentile for chronologic age).

$\mathrm{hSDS}_{\mathrm{CA}}$. It appeared that the mean height for all patients was already below the 3 rd percentile for height $\left(<-1.88 \mathrm{hSDS}_{\mathrm{CA}}\right)$ at the start of the first dialysis. A significant mean decrease of hSDS $_{\mathrm{CA}}$ (Wilcoxon's signed rank test: $p<0.0001$ ) took place during dialysis, amounting to -0.5 (SD 0.7 ) for boys and -0.4 (SD 0.5) for girls. Per year, the change was -0.4 SD for both sexes.

At the time of the first RTx, the mean $\mathrm{hSDS}_{\mathrm{CA}}$ for boys was -3.0 (SD 1.3), and for girls it was -2.3 (SD 1.2). During the next 2 y the mean change in $\mathrm{hSDS}_{\mathrm{CA}}$ was +0.3 (SD 0.8) for boys and -0.1 (SD 1.0) for girls, with only the change in boys being significant $(p=0.03)$. Figure 2 shows the percentage of boys and girls per change in $\mathrm{hSDS}_{\mathrm{CA}}$ during 2 y after their first RTx. A change in $\mathrm{hSDS}_{\mathrm{CA}}$ between +0.5 and $-0.5 \mathrm{SD}$ was seen in $53 \%$ of the boys and $26 \%$ of the girls. An increase in $\mathrm{hSDS}_{\mathrm{CA}}$ over 0.5 SD was found in $32 \%$ of the boys and $31 \%$ of the girls, whereas a decline over 0.5 SD had occurred in only $15 \%$ of the boys but $43 \%$ of the girls.

Impact of various factors on posttransplant growth. Simple linear regression analysis revealed a significant negative association between the change in $\mathrm{hSDS}_{\mathrm{CA}}$ during the 2 y after the first RTx $\left(\Delta h \mathrm{hDS}_{\mathrm{CA}}\right)$ and the following variables: $\mathrm{hSDS}_{\mathrm{CA}}$ at the first $\operatorname{RTx}(p=0.0001)$, Aza versus CsA medication $(p=0.005)$. cumulative dose of prednisone during these two y $(p=0.04)$,

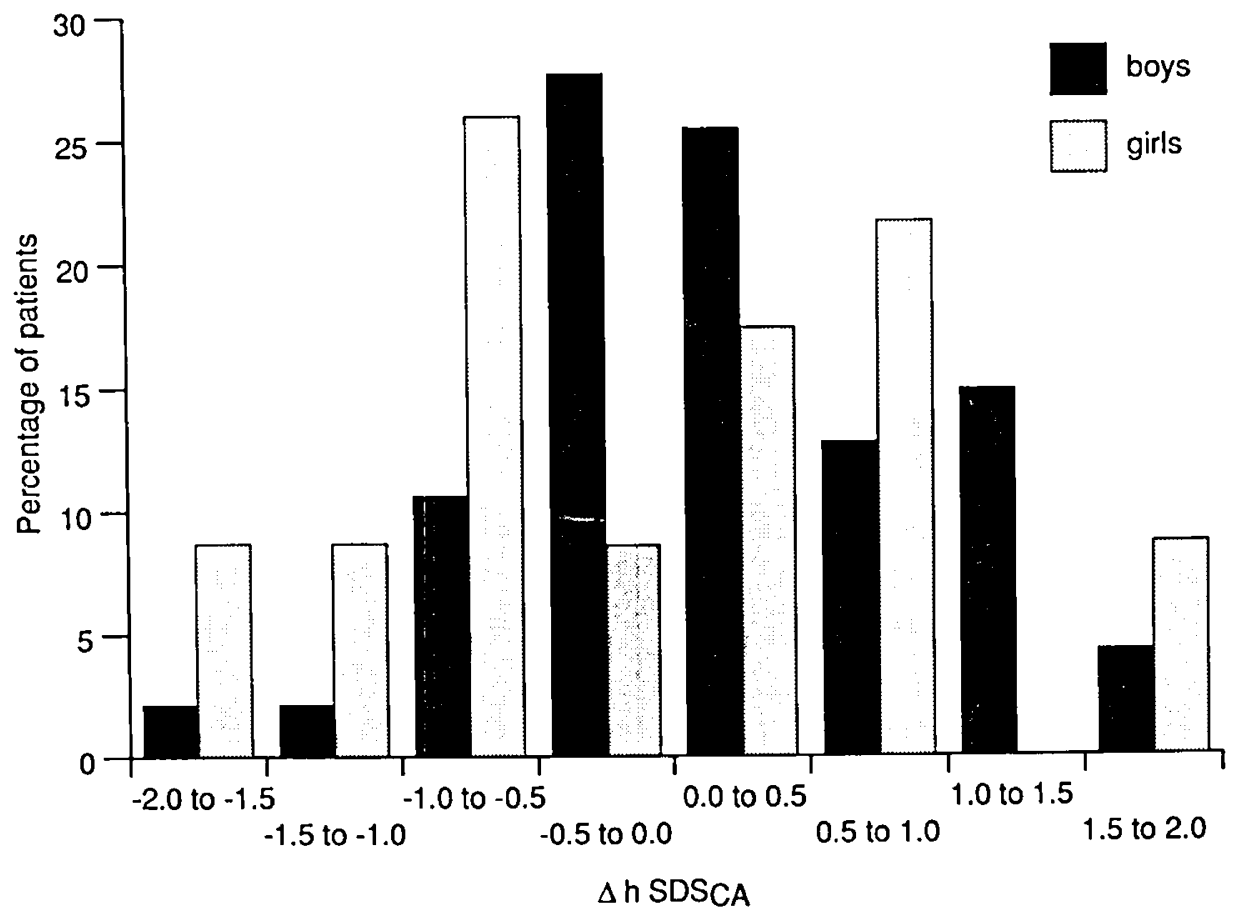

Fig. 2. Percentage of prepubertal boys and girls per change in $\mathrm{hSDS}_{\mathrm{CA}}$ during $2 \mathrm{y}$ after $\mathrm{RT}$. 
and bone age at the time of the first $\operatorname{RTx}(p=0.02)$. A significant positive association was found for the variables: percentage of time on alternate-day prednisone $(p=0.0003)$, and urinary tract abnormalities and/or renal hypoplasia versus other renal disease $(p=0.04)$. Factors that proved not to be significant when analyzed individually were gender, target $\mathrm{hSDS}_{\mathrm{CA}}$, duration of initial dialysis period, age at the first RTx, and duration of GFR less than $50 \mathrm{~mL} / \mathrm{min} / 1.73 \mathrm{~m}^{2}$.

The backward multiple regression analysis performed on the variables known at the time of the first RTx resulted in a model containing only the $\mathrm{hSDS}_{\mathrm{CA}}$ at the first RTx. Subsequent, stepwise backward selection including posttransplant variables revealed the following predictive factors: percentage of time on alternate-day prednisone (\% AD), the cumulative dose of prednisone during the 2-y study period, Aza versus CsA therapy, and duration of a reduced GFR $\left(<50 \mathrm{~mL} / \mathrm{min} / 1.73 \mathrm{~m}^{2}\right)$. The results of this multiple regression model, given in Table 2, provided the following equation for predicting the change in height $\operatorname{SDS}_{\mathrm{CA}}$ $\left(\Delta \mathrm{hSDS}_{\mathrm{CA}}\right)$ in prepubertal children during 2 y after their first RTx:

$$
\begin{gathered}
\Delta \mathrm{hSDS}_{\mathrm{CA}}=0.13-0.30 \times \mathrm{hSDS}_{\mathrm{CA}} \text { at } \mathrm{RTx}+0.01 \times \% \mathrm{AD} \\
-0.19 \times \text { cumulative prednisone }-0.43 \times \text { Aza therapy } \\
-0.28 \times \text { years with GFR }<50 \mathrm{~mL} / \mathrm{min} / 1.73 \mathrm{~m}^{2}
\end{gathered}
$$

The regression coefficient for $\mathrm{hSDS}_{\mathrm{CA}}$ at $\mathrm{RTx}$ was -0.30 , indicating that the increase in $\mathrm{hSDS}_{\mathrm{CA}}$ was smaller when $\mathrm{hSDS}_{\mathrm{CA}}$ at the first RTx was relatively high. In other words, the children who were relatively tall when undergoing their first RTx had less catch-up growth after RTx than those who were shorter at RTx, whose growth retardation had been more severe. Thus, the change in $\mathrm{hSDS}_{\mathrm{CA}}$ of two patients, one of whom is $1 \mathrm{hSDS} \mathrm{C}_{\mathrm{CA}}$ shorter at the first RTx than the other one, will be $0.30 \mathrm{SD}$ more for the shorter patient, provided the other factors are equal.

The regression equation for the prediction of the $\mathrm{hSDS}_{\mathrm{CA}}$ attained 2 y after the first RTx can be derived from the above mentioned regression equation:

$$
\begin{gathered}
\text { Attained } \mathrm{hSDS}_{\mathrm{CA}}=0.13+0.70 \times \mathrm{hSDS}_{\mathrm{CA}} \text { at } \mathrm{RTx}+0.01 \\
\times \% \mathrm{AD}-0.19 \times \text { cumulative prednisone }-0.43 \\
\times \text { Aza therapy }-0.28 \times \text { years with GFR } \\
\quad<50 \mathrm{~mL} / \mathrm{min} / 1.73 \mathrm{~m}_{2}
\end{gathered}
$$

\begin{tabular}{|c|c|c|c|}
\hline Variable & $\begin{array}{l}\text { Regression } \\
\text { coefficient }\end{array}$ & SE & $p$ value \\
\hline $\begin{array}{l}\text { Height } \text { SDS }_{\mathrm{CA}} \text { at first } \\
\text { RTx }\end{array}$ & -0.30 & 0.06 & $<0.0001$ \\
\hline $\begin{array}{l}\text { Percentage of time on al- } \\
\text { ternate-day prednisone }\end{array}$ & 0.01 & 0.00 & $<0.0001$ \\
\hline $\begin{array}{l}\text { Cumulative dose of pred- } \\
\text { nisone (per } 100 \mathrm{mg} / \mathrm{kg} \text { ) }\end{array}$ & -0.19 & 0.08 & 0.02 \\
\hline Aza vs CsA medication & -0.43 & 0.18 & 0.02 \\
\hline $\begin{array}{l}\text { Duration of reduced graft } \\
\text { function }(\mathrm{y})(\mathrm{GFR}< \\
\left.50 \mathrm{~mL} / \mathrm{min} / 1.73 \mathrm{~m}^{2}\right)\end{array}$ & -0.28 & 0.12 & 0.02 \\
\hline
\end{tabular}

The regression coefficient for $\mathrm{hSDS}_{\mathrm{CA}}$ at the first RTx being +0.70 with respect to the $\mathrm{hSDS}_{\mathrm{CA}}$ attained 2 y later has the following implication. For the same two patients cited above,

\footnotetext{
Regression equations: Predicted change in $\mathrm{hSDS}_{\mathrm{CA}}$ during 2 y after $\mathrm{RTx}=0.13-0.30 \times \mathrm{hSDS}_{\mathrm{CA}}$ at $\mathrm{RTx}+0.01 \times \% \mathrm{AD}-0.19 \times$ cumulative prednisone $-0.43 \times$ Aza therapy $-0.28 \times$ years with GFR $<50 \mathrm{~mL}$ / $\min / 1.73 \mathrm{~m}^{2} ; \mathrm{hSDS}_{\mathrm{CA}}$ at $2 \mathrm{y}$ after RTx $=0.13+0.70 \times \mathrm{hSDS}_{\mathrm{CA}}$ at RTx $+0.01 \times \% \mathrm{AD}-0.19 \times$ cumulative prednisone $-0.43 \times$ Aza therapy $-0.28 \times$ years with GFR $<50 \mathrm{~mL} / \mathrm{min} / 1.73 \mathrm{~m}^{2}$.
}

who differ by 1 hSDS ${ }_{\mathrm{CA}}$ at the first RTx, the patient with the most severe growth retardation will be $0.70 \mathrm{SD}$ shorter than the other patient at 2 y after RTx despite better catch-up growth.

The regression coefficient for the percentage of time on alternate-day prednisone was +0.01 which means, for example, that the change in $\mathrm{hSDS}_{\mathrm{CA}}$ of two patients, one on $80 \%$ alternate-day and the other on $0 \%$ alternate-day ( $100 \%$ daily) prednisone, will be $0.8 \mathrm{SD}$ higher for the patient with $80 \%$ alternate-day prednisone, provided all other factors remain equal.

The regression coefficient for the cumulative dose of prednisone was -0.19 , which means that for each additional $100 \mathrm{mg} /$ $\mathrm{kg}$ prednisone administered during the $2-\mathrm{y}$ period, the loss in hSDS $_{\mathrm{CA}}$ increased by $0.19 \mathrm{SD}$.

Aza versus CsA treatment had a significantly negative effect on the 2-y posttransplant growth, amounting to an average growth reduction of $0.4 \mathrm{SD}$ for the patient receiving Aza.

The regression coefficient for duration of reduced GFR was -0.28 , implying that for each year that the GFR remains under $50 \mathrm{~mL} / \mathrm{min} / 1.73 \mathrm{~m}^{2}$, the decrease in $\mathrm{hSDS}_{\mathrm{CA}}$ during $2 \mathrm{y}$ after $\mathrm{RTx}$ will amount to $0.3 \mathrm{SD}$, provided the other factors remain equal.

\section{DISCUSSION}

Our study revealed that the mean $\mathrm{hSDS}_{\mathrm{CA}}$ of the prepubertal study population was already below $-1.88 \mathrm{SD}$ when dialysis was initiated. Subsequently, dialysis resulted in a significant decrease in $\mathrm{hSDS}_{\mathrm{CA}}$, amounting to $-0.4 \mathrm{SD}$ per year for boys and girls alike until this process was halted at RTx. As a result, many children had a substantial degree of growth retardation by the time they had their first RTx. During the 2 y after RTx, only $30 \%$ of these children had an appreciable catch-up growth (i.e. an increase in hSDS $_{\mathrm{CA}}$ of more than +0.5 SD). Other studies have also indicated that few children experience a marked catchup growth after successful RTx $(9,15,16)$. The present findings correspond with the results of our previous study, which indicated that $77 \%$ of men and $71 \%$ of women who had received their first RTx before the age of 15 attained a final height below the 3rd height percentile (hSDS ${ }_{\mathrm{CA}}<-1.88$ ) (Hokken-Koelega $e t$ al., unpublished manuscript).

Until now, the variables that might influence growth during the 1st years after RTx were largely unknown (15). Our study has revealed that five variables simultaneously have a significant influence on the 2-y growth after RTx: $\mathrm{hSDS}_{\mathrm{CA}}$ at the time of the first RTx, percentage of time on alternate-day prednisone, cumulative dose of prednisone, Aza therapy versus CsA or combined CsA/Aza treatment, and duration of reduced graft function $\left(\right.$ GFR $\left.<50 \mathrm{~mL} / \mathrm{min} / 1.73 \mathrm{~m}^{2}\right)$.

Our study showed that the posttransplant growth was best in our patients with the lowest SSDS $_{\mathrm{CA}}$ at the time of their first RTx. Bosque et al. (9) similarly found a significant negative correlation between $\mathrm{hSDS}_{\mathrm{CA}}$ at the first RTx and the subsequent growth in 46 patients. However, our study also revealed that the better catch-up growth after RTx did not in fact compensate for the severe growth retardation at RTx. Multiple regression analysis showed that $h_{S D S}$ at the time of the first RTx has a significant positive effect on the hSDS $\mathrm{CA}_{\text {attained }} 2 \mathrm{y}$ after RTx.

The present study clearly demonstrated that alternate-day prednisone administration has a beneficial effect on growth compared with daily administration, even in the presence of other significant factors. The positive effect of alternate-day prednisone has been reported by others $(9,17)$, but these studies did not differentiate between the effect of either alternate-day or daily therapy coupled with that of other factors. A recent prospective and controlled study analyzed the effect of alternate-day versus daily prednisone therapy on growth during a relatively short period of 14 to 27 mo in a selected group of children with normally functioning renal grafts $(6)$. The authors concluded that the inhibitory effect on growth velocity of a certain cumulative dose of prednisone was significantly less when given on alternate days, without any additional risk of rejection. From 
these results together with our present and earlier findings, one might conclude that alternate-day prednisone administration is preferable to daily administration. However, well-controlled, long-term studies are required to verify that the alternate-day regimen does not increase the risk of renal graft deterioration.

Our study revealed that the cumulative dose of prednisone administered during the $2 \mathrm{y}$ after RTx had a significant negative effect on growth during that period even in the presence of other significant factors. The mode of action of steroids in inhibiting growth is still largely a matter for conjecture. We have recently demonstrated that patients with growth retardation after RTx who had received long-term prednisone therapy had significantly lower 24-h plasma growth hormone levels than healthy controls (18). Others have reported that corticosteroids have a direct inhibitory effect on the cartilage, collagen synthesis, and bone matrix formation (19-21), and corticosteroids had a suppressive effect on IGF-I mRNA levels in several tissues (22). Thus, one of the mechanisms involved in growth retardation after RTx might be the prednisone-induced inhibition of local IGF-I gene expression.

Treatment with Aza appeared to have a significantly negative effect on posttransplant growth compared with CsA treatment. It has been reported that CsA therapy allows for decreased dosage of corticosteroids while improving growth rates $(7,8,23)$. However, the variables Aza therapy and cumulative dose of prednisone each retained a significantly negative influence on posttransplant growth when regarded simultaneously in the multiple regression model. Thus, the improved growth during CsA treatment is not merely attributable to a reduced cumulative dose of prednisone. It has been reported that the GFR of patients treated with Aza was higher than the GFR of patients on CsA (7), although others have found no significant difference in actual graft survival (23). Additional, well-controlled studies are required to verify that CsA treatment does not lead to premature graft failure.

The multiple regression analysis revealed that persistence of a reduced GFR $\left(<50 \mathrm{~mL} / \mathrm{min} / 1.73 \mathrm{~m}^{2}\right)$ has a significantly negative effect on posttransplant growth. In an earlier study, we found a negative correlation between renal graft function and the serum IGF-binding protein-3 levels (18). Consequently, a reduced GFR together with decreased IGF bioavailability may well play a role in the disappointing growth after RTx.

Gender, primary renal disease, duration of the first dialysis period, chronologic and bone age at the time of the first RTx, and target hSDS $\mathrm{CA}$ proved to have no significant effect on the change in $\mathrm{hSDS}_{\mathrm{CA}}$ after RTx when evaluated simultaneously in the multiple regression analyses.

In conclusion, our study shows that $70 \%$ of prepubertal renal allograft patients do not have an appreciable catch-up growth during the first 2 y after RTx. Despite an apparent positive correlation between severe growth retardation at the time of RTx and increased growth immediately after RTx, this increased catch-up growth will not fully compensate for pre-RTx growth retardation. Two years after $\mathrm{RTx}$ the height of the children with severe growth retardation at RTx still lagged behind that of children whose growth retardation was less severe at RTx. Consequently, optimization of the $\mathrm{hSDS}_{\mathrm{CA}}$ at $\mathrm{RTx}$ is very important. Recent studies have demonstrated that biosynthetic growth hormone therapy accelerates growth significantly in children with chronic renal insufficiency, resulting in an improved $\mathrm{hSDS}_{\mathrm{CA}}$ at $\operatorname{RTx}(24,25)$. After RTx, maximum catch-up growth may then be achieved provided the following conditions are met: alternateday instead of daily prednisone administration, a minimal cu- mulative dose of prednisone, CsA instead of Aza treatment, and a GFR above $50 \mathrm{~mL} / \mathrm{min} / 1.73 \mathrm{~m}^{2}$.

Acknowledgments. The authors thank J. Drost-van der Linden for secretarial assistance and A. Ribbink-Goslinga for editing the manuscript.

\section{REFERENCES}

1. Van Diemen-Steenvoorde R, Donckerwolcke RA, Brackel H, Wolff ED, De Jong MCJW 1987 Growth and sexual maturation in children after kidney transplantation. J Pediatr 110:351-356

2. Deleted in proof

3. Rizzoni G, Basso T, Setari M 1984 Growth in children with chronic renal failure on conservative treatment. Kidney Int 26:52-58

4. Kleinknecht C, Broyer M, Gagnadoux MF 1980 Growth in children treated with longterm dialysis: a study of 76 patients. Adv Nephrol 9:133-163

5. Ingelfinger JR, Warren E, Grupe MD, Harmon WE, Fernbach SK, Levey RII 1981 Growth acceleration following renal transplantation in children less than 7 years of age. Pediatrics $68: 255-259$

6. Broyer M, Guest G, Gagnadoux MF 1992 Growth rate in children receivin alternate-day corticosteroid treatment after kidney transplantation. J Pediatr 120:721-725

7. Offner G, Hoyer PF, Juppner H, Krohn HP. Brodehl J 1987 Somatic growth after kidney transplantation. Am J Dis Child 141:541-546

8. Hoyer PF, Offner G, Wonigeit K. Brodehl J, Pichlmayr R 1984 Dosage of cyclosporin $A$ in children with renal transplants. Clin Nephrol 22:68-71

9. Bosque M, Munian A, Bewick M, Haycock G, Chantler C 1983 Growth after renal transplants. Arch Dis Child 58:110-114

10. Tanner JM, Whitehouse RH 1976 Longitudinal standards for height, weightheight, weight-velocity and stages of puberty. Arch Dis Child 51:170-179

11. Roede MJ, Van Wieringen JC 1985 Growth diagrams 1980. Netherlands third nation-wide biometric survey. Tijdschr Soc Gezondheidszorg 63(suppl):134

12. Greulich W, Pyle I 1959 Radiographic atlas of skeletal development of the hand and wrist. Stanford University Press, Stanford, CA

13. Van de Brande JL, Van Gelderen HH, Monnens AH (eds) 1990 Endocrinologie en groeistoornissen. In: Kindergeneeskunde, Bunge. Utrecht. Netherlands, pp 179-219

14. Morris MC, Allanby CW, Toseland P 1982 Evaluation of a height/plasma creatinine formula in the measurement of glomerular filtration rate. Arch Dis Child 57:611-614

15. Fine RN 1987 Growth after renal transplantation in children. J Pediatr 110:414-416

16. Rees L, Greene SA, Adlard P, Jones J, Haycock GB, Rigden SPA, Preece M, Chantler C 1988 Growth and endocrine function after renal transplantation. Arch Dis Child 63:1326-1332

17. Potter DE 1989 Alternate-day versus daily corticosteroid therapy in transplanted children. In: Scharer K (ed) Growth and Endocrine Changes in Children and Adolescents with Chronic Renal Failure: Pediatric and Adolescent Endocrinology, Vol 20. S. Karger, Basel, pp 126-135

18. Hokken-Koelega ACS, Stijnen T, De Muinck Keizer-Schrama SMPF, Blum WF, Drop SLS 1993 Levels of growth hormone, IGF-I and -II, IGFBP-1 and -3 , and cortisol in prednisone treated children with growth retardation after renal transplantation. J Clin Endocrinol Metab 77:932-938

19. Hill DJ 1981 Effects of cortisol on cell proliferation and proteoglycan synthesis and degradation in cartilage zones of the calf costochondral growth plate in vitro with and without plasma somatomedin activity. J Endocrinol 88:425430

20. Allen DB, Goldberg BD 1992 Stimulation of collagen synthesis and linear growth by growth hormone in glucocorticoid-treated children. Pediatrics 89:416-421

21. Chyun YS, Kream BE, Raisz LG 1984 Cortisol decreases bone formation by inhibiting periosteal cell proliferation. Endocrinology 114:477-481

22. Luo J, Murphy LJ 1989 Dexamethasone inhibits growth hormone induction of insulin-like growth factor-I (IGF-I) messenger ribonucleic acid (mRNA) in hypophysectomized rats and reduces IGF-I mRNA abundance in the intact rat. Endocrinology 125:165-171

23. Brodehl J, Offner G, Hoyer PF, Schirg E, Pichlmayr R. Wonigeit K 1986 Cyclosporin $A$ in pediatric kidney transplantation and its effects on posttrans plantation growth. Nephron 44:26-31

24. Tönshoff B, Mehls O, Heinrich U, Blum WF, Ranke M, Schauer A 1990 Growth stimulating effects of recombinant growth hormone in children with end-stage renal disease. J Pediatr 116:561-566

25. Hokken-Koelega ACS, Stijnen T, De Muinck-Keizer-Schrama SMPF, Wit JM, Wolff ED, De Jong MCJW, Donckerwolcke RA, Abbad NCB, Bot A. Blum WF, Drop SLS 1991 Placebo-controlled, double-blind cross-over trial of growth hormone treatment in prepubertal children with chronic renal failure. Lancet 338:585-590 